\title{
Indonesian Model Foreign Direct Investment (Omnibus Law): Learning from China
}

\author{
Diana Setiawati ${ }^{1}$, Chrisna Bagus Edhita Praja ${ }^{2}$, Hary Abdul Hakim ${ }^{3}$, Muhammad Bagus Boy \\ Saputra $^{4}$ \\ \{diana.setiawati96@gmail.com ${ }^{1}$ \}
}

Department of Financial and Economic Law, Asia University, Taiwan ${ }^{1}$

Faculty of Law, Universitas Muhammadiyah Magelang, Indonesia ${ }^{2,3,4}$

\begin{abstract}
The paper responds on critical aspects between Indonesian Foreign Direct Investment Regulation (FDI) Act and China Foreign Investment Laws (FIL). China is relatively more developed, socially and economically over other countries, as viewed by scholars and foreign investors as an ideal place for foreign direct investment, partly due to its well-educated population, low labor costs, natural resources, and the adoption of an open-door policy. China have made remarkable FDI accomplishment through their own ways. Meanwhile, Indonesia is using an omnibus legislative strategy to entice foreign investors to invest in the country by modifying 74 FDI regulations. The study took a comparative approach to normative legal research. In addition, the goal of this study is to introduce the FDI legal model to Indonesia. And explores the debate issue on whether creating the omnibus law is a contradiction to Indonesian legal system. Moreover, intends to conclude by arguing that Indonesia should reconsider the omnibus law approach and refer to the lesson from the experience of China and Singapore.
\end{abstract}

Keywords: Foreign direct investment, omnibus law, china

\section{Introduction}

As modern businesses develop opportunities in a globalized market, FDI has become a key issue of discussion on corporate boards around the world. Businesses are discovering that failure to participate in foreign direct investment could spell their doom in today's economy, which operates on a larger scale than ever before [1]. Southeast Asia's export-led growth has heavily relied on FDI.

FDI from developing countries has increased significantly in recent years, particularly since the mid-1980s. This period also saw the initial stages of a shift in the motivations for those countries' FDI flows. Recently, their enterprises have increased their reliance on outward FDI as a strategic tool for enhancing their international competitiveness..

The United States officially removed Indonesia and a number of other nations, including South Korea, Thailand, Singapore, and Vietnam, from the list of emerging and developing countries in February 2020 [2]. Under the World Trade Organization's Agreement on Subsidies and Countervailing Measures, Indonesia will no longer qualify for special differentiated treatment (SDT).

In order to handle this new international situation, Indonesia as a developed country has tried to revise her investment regulations and creates an omnibus law as the solution to attract 
foreign investor to invest in Indonesia. This is a strategy to develop the country's economy. Foreign direct investment first entered Indonesia in the Suharto era, and has been exist until nowadays. FDI in Indonesia has grown rapidly in developing infrastructure and some strategic industries. But the number of foreign investors remain limited, some foreign investors are not interested in investing in Indonesia because of Indonesia's strict investment regulation. High labor cost is also one of the considerations for foreign investors hesitating in investing Indonesia. On the other hand, the momentum of investment reallocation from China provides an opportunity to investment to Indonesia today.

To improve the ranking and increas the number of foreign investors to make improvement for Indonesian economic conditions, on October 2019 President Joko Widodo gave a mandate to the parliament on making new regulations that can ease investment procedures and provide more incentives for investors. Indonesian President Joko Widodo's government proposed a draft bill to the country's parliament in February 2020. The "omnibus law," as it is known, is a draft that aspires to alter Indonesia's economy. On October 5, 2020, the bill of omnibus law has been promulgated by the House of Representatives as the job creation act.

Investment laws and policies are characterised by an understanding of the important role of investment in economic growth and development, as well as the significance of investment policies as a component of development strategies. It also fosters sustainable development by balancing social and environmental goals with economic growth and development goals through responsible investment. Furthermore, everyone agrees that improving the effectiveness of investment-promoting and encouraging policies is critical. These characteristics of newgeneration investment strategies are reflected in specific national and international investment policy concerns [3].

In terms of FDI, it is necessary if Indonesia may learn lesson from other countries, such as China and Singapore. Foreign direct investment (FDI) has delivered China as a superpower a great deal of money and economic success, and it has played a crucial part in China's development. The legal culture and regulatory process, on the other hand, necessitate patience and perseverance. In 2019, China received the largest foreign direct investment in two years, although outbound investment fell as capital controls were implemented. FDI increased 5.8\% year on year to 941.5 billion yuan ( $\$ 136.71$ billion), the highest increase since 2017 , when it increased $7.9 \%$ in yuan terms. China remains the world's second-largest recipient of FDI. [4].

This article will examine the foreign direct investment legal model in China and its implementation of FDI regulation. Moreover, discuss and analyses the legal model of foreign direct investment in Indonesia related to the issues on creating an omnibus law and lesson learned from China.

\section{Method}

This study employs a statute-based approach and concentrates on the process of developing legal rules and legal doctrines in attempt to face legal issues in Indonesia. This research relies on secondary data. The information was gathered through library research and a review of legal documents. The literature is filtered for primary legal resources, secondary legal materials, and tertiary legal elements. The core legal materials are derived from 74 investment-related acts governed by Indonesian regulations. Secondary legal materials are those that are closely related to primary legal resources and can help with the analysis. They include: a. related scientific publications; b. journals and associated literature; c. the findings of connected studies; and d. 
doctrines, views, and oral and written testimony from legal experts. Dictionaries and encyclopedias are examples of tertiary legal materials.

This research study takes a comparative approach, analyzing and comparing the Indonesian FDI legal model to that of China. Another approach is one that is applied to various laws or regulations relating to Foreign Direct Investment regulation and its implementation. The legal materials for this study, which include primary, secondary, and tertiary sources, were gathered from: a. various libraries; b. printed and electronic media.

Primary, secondary, and tertiary legal materials were used in this normative legal research. The method employed to gather these legal materials is known as documentary study. A documentary research analyses data related to existing legal regulations or documents.

In this study, the researcher uses qualitative prescriptive analysis, in which the researcher analyzes the subject and object of the research and provides an interpretation or disclosure. This study will also use a case study approach to analyze the issues raised by the Indonesian president's instruction to revise the 74th investment act and his proposal to create an omnibus law governing both domestic and foreign investment in Indonesia, and will then discuss the Indonesian FDI legal model and compare it to the Chinese FDI legal model. In this study, the researcher made no attempt to substantiate his or her findings.

\section{Results and Discussions}

\subsection{Indonesian Foreign Direct Investment}

The Foreign Investment Law, which was first passed in 1967 and revised in 1970, and again in 2007, governs foreign direct investment in Indonesia. Since 1970, a series of more or less annual deregulation measures in the form of new regulations produced by various ministries or agencies have been implemented. Each one makes it easier and more appealing for foreign investors to engage in Indonesia's economic progress.

Apart from Indonesian Law No. 40 of 2007 on Limited Liability Companies (often referred to as the "Company Law"), Law No. 25 of 2007 on Capital Investment is another important law governing (foreign) investment in Indonesia (henceforth "Investment Law"). The 2007 Investment Law, on the other hand, places a stronger focus on new investment, investment incentives, and investor rights. This Investment Law, which applies to direct investments in all industries, tackles all of the major issues that investors have when establishing a firm in Indonesia [5].

It is undeniable that the presence of foreign investors in Indonesia is one of the important factors in developing the country. Historically, foreign investment has good rate in the Suharto era. During of 1980 to 1997 until 1998 when the economic crisis happened, it had been a golden period of the growth of foreign investment in Indonesia.

The 2007 Investment Law covers both domestic and foreign investment. Foreign nationals and foreign-incorporated firms are the two types of foreign investors. Any "investment activity for the purpose of conducting a business" that is owned or financed in part by a foreign investor is considered foreign investment. Furthermore, any foreign investment in Indonesia must be made through an Indonesian limited liability company, according to the Investment Law (FDI Act).

Investment law establishes the general principle that all market fields are open to both domestic and foreign investment, with the exception of those that are expressly deemed closed 
and those that are declared open to investment subject to conditions, such as limits on the amount of foreign ownership allowed. The legal basis for investment restrictions and requirements is a range of laws and regulations. The Investment Law, on the other hand, stipulates that these prohibitions be consolidated into a single Presidential Regulation. Presidential Decree 44/2016, which replaces Presidential Regulation No. 39/2014, is the most recent version of this "Negative List" of investment limitations and constraints.

The World Bank predicteds economic growth in developing countries would drop to the lowest level in four years by $4 \%$ in 2019. The Indonesian government has sought to overcome the effects of financial pressures and weak economic growth by offering foreign investors interested in investing in Indonesia through the revision of 74 laws that could hamper the attractiveness of foreign investors.

In the last few years, the Government has been active in making efforts to attract investors to enter Indonesia. The policies undertaken include simplifying the licensing process by reducing obstacles to starting a business, especially in terms of licensing procedures, revising the Negative Investment List (DNI), and increasing tax incentives. The government argues that the revision of the DNI is part of efforts to promote sluggish economic growth and to attract the foreign investor.

President said this investment negative list can obstruct foreign investor to invest in Indonesia, Based on this situation, in 2019, Jokowi, as the president of Indonesia, gave an instruction to the new ministry to revised 74 investment Acts President Jokowi hope that after revising the investment regulation Indonesia can attract more foreign investors to invest in Indonesia [6]. This is very interesting to be re-examined regarding the revision of the investment Act because it caused a lot of controversy and political interests.

Looking the fact that happened now in Indonesia, which the ratification of the omnibus law seems very rushed and there are lots of typos in the writing of the law. As a result, this has drawn a lot of controversy and arise public protest. The Indonesia omnibus law (recently known as job creation act) Indonesia's Omnibus Law which was passed on 5 October 2020 that sign by President Joko Widodo. Exhibits had started the omnibus bill in 13 January 2020. From the beginning, public society are protest with the government plan on issuing omnibus law.

So this raises a separate question for the author, whether to attract foreign investors requires a revision of the law or can be done in other ways. Then the authors want to see how the strategies of other countries such as China and Singapore in attracting foreign investors. And, using a comparative method research to learn from the experiences of China as a superpower country and Singapore as a major foreign investor in Indonesia, this thesis will explore and analyze the legal model of FDI in China and Indonesia.

\subsection{The Model of Foreign Direct Investment in China}

China's legal system was built by two the great tradition, namely the legal system which originates from the teachings of the philosophy of Confucianism, which rests on the devotion to the rules of moral law (called as: li = 禮 [礼] 《禮》). And a legal system based on statute (called fa = 法), especially criminal law, as a legal product that kings attempted with the help of legal experts. The emergence of the concept of $\mathrm{Li}$ in the Chinese legal system, is based on the Chinese social structure in the kingdom era which is based on ethics derived from three schools of thought, namely: Confucianism, Taoism and Buddhism. Li is the closest keyword to the meaning of "law" according to legal conceptions in western countries, although sometimes $\mathrm{Li}$ is also translated as ritual, morals, etiquette, and certainty. Li is a set of rules of propriety and 
decency that honest humans must heed. Thus Li shows more as a code of ethics in social relationships (moral rules) [7].

China has grown into a global economic superpower during the previous three decades. This level of transformation did not happen by accident; policies and new regulations paved the way. As a result, the legal system in China is still developing. The law contains gaps and ambiguities, and policy can change quickly and abruptly, not necessarily to everyone's favor. As a result, while there are economic opportunities and a strong legal framework to support them, the legal climate remains hard.

The People's Republic of China (PRC) has a legal system based on the PRC Constitution, which was last revised in 2004. Written legislation, regulations, and administrative directives are used to organize it in a hierarchical manner. The people, through municipal, provincial, and national congresses of representative people, exercise legislative authority from the bottom up, according to the Constitution. [8].

The FDI legal framework has been gradually formalized and clarified:

a. A basic notion for the development and operation of foreign economic entities was directed by the 1979 Law on Joint Ventures Using Chinese and Foreign Investment. It outlined a number of joint venture incentives and terms.

b. The Law on Joint Ventures Using Chinese and Foreign Investment Regulations of 1983 contained more information on joint venture operations and preferential policies.

c. The formation of totally foreign-owned firms outside of SEZs was explicitly permitted by the 1986 Law on Enterprises Exclusively Run with Foreign Capital.

d. 1986 Notifications for some further advancement of the situations for the implementation of foreign investment undertakings, as well as State Council regulations promoting foreign investment, provided additional incentives, particularly for FDI that used advanced technology and/or exported-oriented manufacturing. The Cooperative Joint Ventures Act of 1988 codified these provisions.

e. 1990 The revisions to the Implementing Regulations for Joint Ventures and Wholly Foreign-Owned Companies developed a more complete legal framework to make these undertakings easier to carry out. These laws/rules, in particular, removed the need that a joint venture's chairman of the board of directors be nominated by Chinese investors and established nationalization immunity.

f. The Interim Foreign Direct Investment Guidance Provisions of 1995 (updated in 1997) divided FDI into four categories.

According to the United Nations Conference on Trade and Development, China's total foreign direct investment (FDI) hit US\$2.1 trillion at the end of 2018, putting it second in the world (UNCTAD). However, China's ease of doing business is ranked 46th in the world by the World Bank, trailing a number of countries including the United States, Malaysia, Germany, and Russia. It's simple to see why China needs a law like the FIL to create a more open and transparent business environment for foreign investment in this scenario.

Additionally, the law change may contribute to the establishment of a law-based environment that is more consistent with international practices in protecting foreign investors' legitimate rights and interests. The new law demands that local governments standardize their administrative procedures for foreign investment and ensure that their officials follow the law. Abuse of authority, disregard of duty, self-seeking misconduct, and the leaking of trade secrets are all examples of illegal activity that could lead to criminal charges. Furthermore, the integrated foreign investment administration law may eliminate future confusion for new foreign investors, making the process of investing and doing business in China more straightforward. 
China who's already success on attract FDI has some strategy that china use to handle their FDI, and here are some strategy that china used to attract FDI, and we can learn from those strategy, The strategy such as:

a. Tax concession, special privilege, and open economic zone policies

b. Legal Environment and low of Corruption

c. Low wage costs, and improved infrastructure

d. Strong Political Leadership.

\subsection{Dilema of Establishment of Indonesian Omnibus Law}

Omnibus legislation is defined as (1) a single measure that addresses multiple issues. To oblige the executive branch to either adopt or overturn all-important provisions established in this manner. (2) A bill that includes all suggestions on a single issue, such as a 'omnibus judgeship bill,' which includes all ideas for new judgeships, or a 'omnibus crime bill,' which includes new crimes and crime-control measures. (3) Omnibus bills are formal proposals to alter laws that rank-and-file legislators vote on and send to the executive branch for ultimate approval, similar to ordinary bills. The difference between omnibus bills and other bills is that omnibus bills contain a number of smaller bills that are nominally on the same general subject. Consider the omnibus tax bill: it might include adjustments to income, corporation, and sales taxes, but all of these concerns could be grouped together.

Simply describe an omnibus law or omnibus bill is a single Act that has the power to modify many laws. On September 28, 2017, Jimly Asshiddiqie stated three scenarios for practicing omnibus law, namely the Law to be amended directly, the Law to be amended is not directly related, and the Law to be amended is not directly related but in related practice.

Sofyan Djalil, the Coordinating Minister for Economic Affairs of the Republic of Indonesia at the time, was the driving force behind the omnibus bill in Indonesia. He argues that the investment process in Indonesia is still very difficult and convoluted. The length of bureaucratic chains, overlapping regulations across ministries, and the number of disharmony regulations are factors that hinder the ease of investment in Indonesia.

To make the processing of company licenses in Indonesia easier, the government enacted government regulation (PP) No.24 of 2018 on the Electronically Integrated Business Licensing Service, also known as the Online Single Submission (OSS), yet this isn't adequate. "There are at least 10 to 11 rules governing the licensing of enterprises and supposedly complicating investors," said Darmin Nasution, the Coordinating Minister for Economic Affairs of the Republic of Indonesia. To alter the 10 to 11 Act, an omnibus bill will be drafted.

More than $90 \%$ of the law is really intended to stimulate domestic and foreign investment by eliminating bureaucratic inefficiencies and excessive approval necessities because hazy, overlapping and contradictory regulations have long hindered competitiveness. The omnibus legislation amends 79 laws and removes thousands of products that detriment to business, investment and also draw foreign investors (FDI). The Indonesian House of Representatives was incited to underwrite the omnibus bill by the hopeless disappointment of very nearly 20 change bundles that were dispatched from 2015 to 2019. Those changes were to a great extent incapable on the grounds that their execution was sabotaged by the administrative cover and strife getting from around 80 laws just as a huge number of official guidelines and ecclesiastical announcements.

Thousands of Indonesians marched for the third day against a disputed law that opponents fear will hurt workers and the environment, after the bill (omnibus bill) was already changed into a regulation (job creation act). In Jakarta, hundreds of people have been detained. Hundreds 
more have been detained this week as a result of strikes and protests in other towns. The administration claims that the reforms are required to help the country's economy, which has been hit hard by the Covid-19 outbreak. Demonstrations have gained traction in Jakarta, Tangerang, Banten, Bogor, Bekasi, Karawang, Purwakarta, Subang, Cimahi, Sumedang, Bandung Raya, Garut, Tasikmalaya, Indramayu, Cirebon, and Semarang, among other cities. Then there are cities like Yogyakarta, Solo, Blora, Gresik, Surabaya, Sidoarjo, East Kalimantan, Makassar, Lampung, South Sumatra, Riau, Jambi, North Sumatra, Batam, NTT, and others. Seven out of nine parties voted in favor of the omnibus bill, which is over 1,000 pages long and alters 79 existing laws.

The government believes that the employment growth act, often known as the omnibus law, is intended to simplify Indonesia's complicated web of commercial, labor, and environmental laws in order to speed licensing and bureaucracy [process]. We want speed, so a legal harmonisation is required to provide speedy services and policy decisions, allowing Indonesia to respond to global changes more quickly. But in the reality, this regulation is from the nation is facing rejection from the nation. The 1,187-page law, which contains 79 statutory-level regulations, continues to face widespread opposition from the public, particularly labor groups, who view it as a "serious threat" to workers' rights. While a few labor organizations chose to challenge the law in the Constitutional Court, others chose to continue protesting it.

Simplification of Licensing, Investment Requirements, Employment, Ease of Doing Business, Empowerment and Protection of MSMEs, Research and Innovation Support, Government Administration, Imposition of Sanctions, Land Acquisition, Ease of Investment and Government Projects, and Areas Special Economics are all discussed in the Job Creation Act. The labor cluster is considered to have many controversial articles and has been heavily protested by workers. This cluster revises many articles in Law No. 13 of 2003 which have been managing labor issues in Indonesia. That workers rejected 7 things in the Job Creation Act, such as:

a. Full Requirement of Minimum Wage

b. Severance Payment is Reduced

c. Employment Contract without Limited Times

d. Lifetime Outsourching

e. Excessive Working Time.

\section{Conclusion}

In Indonesia the number of foreign investors is limited, in order to improve the number of foreign investors to make improvement for Indonesian economic conditions, on October 2019 President Joko Widodo gave a mandate to the parliament on making new regulations that can ease investment procedures and provide more incentives for investors. Indonesian President Joko Widodo's government proposed a draft bill to the country's parliament in February 2020. The "omnibus law," as it is known, is a draft that aspires to alter Indonesia's economy. The bill of omnibus law known as the job creation act was promulgated by the House of Representatives on October 5, 2020, and signed by President Joko Widodo.

This is the first time to create an omnibus law in Indonesia. Based on some scholar opinion, omnibus law is commonly used in countries with a common law system and Indonesia is a civil law system, this cause arise controversy. On the making proses of omnibus law also considered 
not in accordance with the procedure because the lawmaking is done in a closed, not transparent, and does not provide space for civil society participation.

Foreign direct investment (FDI) has delivered China as a superpower a great deal of money and economic success, and it has played a crucial part in China's development. China's approach for attracting FDI include tax concessions, open economic zone regulations, the legal environment, legal culture, and regulatory procedure, minimal corruption, cheap labour costs, enhanced infrastructure, and political leadership.

\section{References}

[1] Laura Alfaro \& Maggie Chen, U.S. Int'l Trade Comm., Surviving the Global Financial Crisis: Foreign Direct Investment and Establishment Performance 2-5 (2010), http://www.usitc.gov/research_and_analysis/economics_ seminars/2010/Alfaro_and_Chen_GlobalFinancialCrisis.pdf (asserting that FDI plays a critical and complex role in surviving the current global financial crisis).

[2] Riri ranggasari, US Removes Indonesia from Developing Countries List, February 24,2020. Available at: https://en.tempo.co/read/1311451/us-removes-indonesia-from-developing-countrieslist, Accessed on Friday 9 October 2020.

[3] Melody Nyangara \& Davis Nyangara \& Godfrey Ndlovu \& Takawira Tyavambiza, 2016. "An Empirical Test of the Validity of the Capital Asset Pricing Model on the Zimbabwe Stock Exchange," International Journal of Economics and Financial Issues, Econjournals, vol. 6(2), pages 365-379

[4] Xinhua, China remains second largest FDI recipient in 2019: UNCTAD. Available at: http://www.xinhuanet.com/english/2020-01/21/c_138721848.htm. Accessed on, Monday October 12, 2020 12.24 AM.

[5] Yackee, J. W. (2008). Bilateral Investment Treaties, Credible Commitment, and the Rule of (International) Law: Do BITs Promote Foreign Direct Investment? Law \& Society Review, 42(4), 805-832. doi:10.1111/j.1540-5893.2008.00359.x

[6] Gopalan, S., Hattari, R., \& Rajan, R. S. (2016). Understanding foreign direct investment in Indonesia. Journal of International Trade Law and Policy, 15(1), 28-50. doi:10.1108/jitlp-01-2016-0003

[7] Poznanski, K. (2017). Confucian economics: how is Chinese thinking different? China Economic Journal, 10(3), 362-384. doi:10.1080/17538963.2017.1370170

[8] Surya Deva, (2011), The Constitution of China: What Purpose Does it? (Not) Serve?, Jinda Global Law Review, Vol. 2 No. 2 pp. 55-77. 